\title{
FAILURE ANALYSIS OF REFINERY HYDROGEN RECIPROCATING COMPRESSORS
}

\author{
Pawel BIALEK ${ }^{1}$, Piotr BIELAWSKI ${ }^{2}$ \\ ${ }^{1}$ Grupa LOTOS S.A. \\ 135 Elbląska St., 80-718 Gdańsk, Poland, e-mail: pawel.bialek@ grupalotos.p1 \\ ${ }^{2}$ Maritime University of Szczecin, 2-4 Willowa St., 71-650 Szczecin, Poland \\ e-mail: p.bielawski@am.szczecin.pl
}

\begin{abstract}
Hydrogen compressors perform specific functions in the technical system of crude oil processing. The authors characterize consequences of wear margin loss of the compressor, present design solutions of hydrogen piston compressor and divide its construction into functional units. The compressor fault analysis is based on post repair documentation of compressors maintained according to their service life, and making use of technical diagnostics applied to 21 compressors, covering the last 20 years. The analysis distinguishes the loss of compressor wear margin due to loss of functional unit wear margin and due to damage to a compressor component. Faults typical of hydrogen compressor elements have been described. Besides, the authors estimate fault risks for selected elements and risks of wear margin loss of selected functional units. Statistical data are given in tables and bar charts. The analysis outcome indicates the need to implement methods and tools for diagnosing the cylinder unit, comprising several functional units.
\end{abstract}

Keywords: refinery, hydrogen compressors, piston machine faults, fault analysis, diagnostic of reciprocating compressors

\section{ANALIZA USZKODZEŃ TŁOKOWYCH SPRĘŻAREK WODORU UŻYTKOWANYCH W RAFINERIACH}

\begin{abstract}
Streszczenie
Opisano zadania sprężarek wodoru w systemie technicznym przetwarzania ropy naftowej. Scharakteryzowano następstwa utraty potencjału eksploatacyjnego sprężarki. Przedstawiono rozwiązania konstrukcyjne tłokowych sprężarek wodoru użytkowanej w rafinerii. Analizę uszkodzeń sprężarek przeprowadzono $\mathrm{w}$ oparciu o badania dokumentacji poremontowej, obsługiwanych według resursu oraz z wykorzystaniem metod diagnostyki, 21 sprężarek z ostatnich 20 lat. W analizie uwzględniono fakt, że w przypadku sprężarek obsługiwanych według resursu podczas remontu po upływie z góry ustalonego czasu użytkowania wymieniane są elementy sprężarki, których potencjał eksploatacyjny nie został jeszcze wyczerpany. Stwierdzono około 500 przypadków utraty potencjału eksploatacyjnego analizowanych sprężarek. W analizie rozróżniono utratę potencjału eksploatacyjnego sprężarki z powodu utraty potencjału eksploatacyjnego danego zespołu funkcjonalnego sprężarki i z powodu uszkodzenia elementu sprężarki. W artykule zamieszczono opisy wybranych uszkodzeń wybranych elementów sprężarki. Oszacowano ryzyko uszkodzenia wybranych elementów i ryzyko utraty potencjału eksploatacyjnego wybranych zespołów funkcjonalnych. Dane statystyczne zestawiono w formie tabel i wykresów słupkowych. Stwierdzono, że: elementom można przypisać charakterystyczne dla sprężarek uszkodzenia; liczba przypadków utraty potencjału sprężarki zależy od składu sprężanego gazu; największy udział procentowy w uszkodzeniach elementów mają pierścienie uszczelniające zaworów oraz sprężyny dociskowe zaworów; największe ryzyko jest związane $\mathrm{z}$ uszkodzeniami pierścieni tłokowych jako elementów oraz łożysk (w tym wodzika) jako zespołów funkcjonalnych, $\mathrm{z}$ uwagi na poważne $\mathrm{w}$ skutkach uszkodzenia wtórne; największy udział procentowy mają zawory jako zespoły funkcjonalne, z największym ryzykiem związana jest utrata potencjału zespołu cylindra: tłok, pierścienie, tuleja cylindrowa, uszczelnienie gazowe, zawory robocze.
\end{abstract}

Słowa kluczowe: rafineria, sprężarki wodoru, uszkodzenia maszyn tłokowych, analiza uszkodzeń, diagnostyka sprężarek tłokowych

\section{INTRODUCTION}

Piston compressors for hydrogen as items in the refinery production system perform essential functions in crude oil processing. Failures of these machines are considered as very expensive due to costs resulting from the wear margin loss and repair technology used. In addition, due to the compressed medium, hydrogen compressors breakdowns involve high risks for human life and/or health. Although various diagnostic tools are employed in the operation and maintenance of compressors, the effects of their use are not yet quite recognized in case of hydrogen compressors. Therefore, there is 
a need for a compressor fault analysis and review of diagnostic methods aimed at matching the development of methods and diagnostic tools to actual demand. This paper aims at a fault analysis of hydrogen piston compressors operated at Grupa LOTOS S.A.

\section{FAILURES OF PRODUCTION SYSTEM ITEMS}

A refinery is an industrial enterprise characterized by profitability, competitiveness, innovations and product market share. Specific figures representing these characteristics depend to a large extent on the values of quality measures of the production system composed of human-machine interfaces. The quality of a production system is primarily characterized by adequacy, reliability, safety, durability and efficiency. If a real value of a production system item quality measure is lower than a desired value, the item can be regarded as faulty, or unfit for continuing to perform its functions. The item is said to change from up state to down state, or that item's wear margin has been exhausted $[3,4]$. An item in the down state or one with exhausted wear margin is considered as failed. In an enterprise, items are adjusted to the needs of that enterprise, and the operated items are subjected to activities known as maintenance. Maintenance is organized, and the related term is maintenance management. The EN 13306:2006 standard [23] defines maintenance and maintenance management as follows:

Maintenance: combination of all technical, administrative and managerial actions during the life cycle of an item intended to retain it in, or restore it to, a state in which it can perform the required function.

Maintenance management: all activities of the management that determine the maintenance objectives, strategies, and responsibilities and implement them by means such as maintenance planning, maintenance control and supervision, improvement of methods in the organization including economical aspects.

The hydrogen compressor as a production system item consists of functional units performing partial tasks. Similarly, functional units are a set of elements co-operating in functional unit nodes [3, 4]. An item failure may therefore be a result of a failure of a functional unit, a node (a few elements of a functional unit) or just one element.

The decision recognizing an item as failed (damaged) can be made directly by the direct user (operator) and/or by the item's maintenance performer. The direct user, while making a decision, takes mainly into account the item capability - an attribute that contributes to item effectiveness. Decisions of a maintenance performer may be based on:

- efficiency - characteristic describing the effectiveness of an item;
- hazardousness and harmlessness - attributes describing item safety;

- availability - attribute describing item dependability.

Specific criteria for evaluating the technical condition of an item stem from existing legislation, company standards and operational and maintenance manual. For a decision-maker a failure occurrence may be a fact predictable in time or sudden (possible, but unpredictable in time). The same may apply to failures of functional units and functional unit nodes. As a rule, the identification of a failure of functional unit element is possible only after the operating item is stopped and disassembled.

To ensure required availability, a scheduled preventive overhaul is carried out, in which an item is stopped at a preplanned time, disassembled, its elements are verified, repaired and assembled. The verification of elements is aimed at evaluating the condition of elements subject to wear. An element is regarded as failed even if at the time of verification it is not failed, but its failure may occur before the next scheduled overhaul. In some cases, certain elements are replaced with new elements during such maintenance without examining their actual condition. When a scheduled-preventive overhaul is carried out, so-called 'technological damage' to elements occurs, damage due to the technology of disassembly: in some cases a functional unit node cannot be removed without damage to one of its elements.

Scheduled-preventive overhauls cause relatively frequent stoppages of machinery resulting in production losses. It should be noted that also in the case of a redundant machine its shutdown involves high risk as the system availability is not secured in case a failure occurs to the main/working machine. An alternative to scheduled-preventive overhaul are overhauls performed after it becomes known that the wear margin of an essential node of an item has been exhausted. Information on the exhausted wear margin may come from diagnostic systems permanently or temporarily installed on a given item. However, diagnostic systems increase investment project costs and raise requirements for item users and maintenance performers. Therefore, what a company should put in place is a policy of multi-faceted management of technical systems. Such policy is known in the literature as asset management. Asset management uses achievements of the area of knowledge called terotechnology. According to [7] terotechnology can be defined as the study and management of technical systems from their design to removal and disposal.

A company-specific asset management is difficult and requires external support. For reciprocating compressors at the refinery such support comes in the form of API 618 standard (American Petroleum Institute): Reciprocating Compressors for Petroleum, Chemical, and Gas Industry Services [26]. 
This standard is based on the accumulated knowledge and experience of manufacturers and users of reciprocating compressors. The objective of this standard is to provide a purchase specification to facilitate the procurement and manufacture of reciprocating compressors for use in petroleum, chemical, and gas industry services. The primary purpose of this standard is to establish minimum requirements. Energy conservation is of concern and has become increasingly important in all aspects of equipment design, application, and operation. Thus, innovative energy-conserving approaches should be aggressively pursued by the manufacturer and the user during these steps. Alternative approaches that may result in improved energy utilization should be thoroughly investigated and brought forth. This is especially true of new equipment proposals since the evaluation of purchase options will be based increasingly on total life costs as opposed to acquisition cost alone. Equipment manufacturers, in particular, are encouraged to suggest alternatives to those specified when such approaches achieve improved energy effectiveness and reduced total life costs without the sacrifice of safety or reliability. This standard requires the purchaser to specify certain details and features. Although it is recognized that the purchaser may desire to modify, delete, or amplify sections of this standard, it is strongly recommended that such modifications, deletions, and amplifications be made by supplementing this standard, rather than by rewriting or incorporating sections thereof into another standard. Users of this standard should be aware that further or differing requirements may be needed for individual applications. This standard is not intended to inhibit a vendor from offering, or the purchaser from accepting, alternative equipment or engineering solutions for the individual application. This may be particularly applicable where there is innovative or developing technology. Where an alternative is offered, the vendor should identify any variations from this standard and provide details [26].

According to [26] Operating and Maintenance Manuals, a manual containing all required operating and maintenance instructions shall be supplied no later than two weeks after all specified tests have been successfully completed. Torque values for all studs and bolting shall be included in the manufacturer's instruction manual. Operation and maintenance manual, (see 9.3.7.3 [26]) describing the operating and maintenance procedures, requirements and limitations for the complete train and auxiliary equipment, including but not limited to the following:

1. Initial commissioning and start-up, including final tests and checks.

2. Normal start-up

3. Normal shutdown.

4. Emergency shutdown.
5. Operating limits

6. Lube-oil recommendations, including injection rates and specifications.

7. Routine operational procedures.

Maintenance, disassembly, repair and reassembly instructions for the complete train and auxiliary and accessory equipment including but not limited to the following:

1. Valve overhaul data.

2. Cylinder overhaul data.

3. Table of bolt torques. The required torque values or elongations for tensioning the valve cover, valve hold down bolts, connecting rod and main bearing bolts, piston and crosshead nuts, flange bolts and any other bolts that the vendor feels are critical. Data should be included for fasteners in both the lubricated and non-lubricated condition.

4. Fits and clearances for wearing parts, recommended, maximum and minimum.

6. Routine maintenance requirements.

7. Maximum allowable crankshaft web deflection.

At Grupa LOTOS S.A. refinery the wear of elements is assessed using the values specified in the technical documentation of each hydrogen reciprocating compressor $[11,16,17,18,19,20,21$, $27,28]$. This documentation has been prepared according to design and manufacturing standards relating to specific machines.

This article analyzes failures of elements and functional unit nodes that were observed during the verification of elements. Failed elements are understood as elements whose replacement was stated in post-failure reports [24].

\section{STRUCTURAL ANALYSIS OF HYDROGEN PISTONS COMPRESSORS OF GRUPA LOTOS S.A.}

Hydrogen pistons compressors used in the installations of Grupa LOTOS S.A. have the following process applications:

- hydrogen production,

- hydrotreating,

- hydrocracking,

- catalytic reforming,

- hydrodesulfurization.

Table 1 lists main features of hydrogen compressors: Nuovo Pignone, Thermodyn, Thomassen Compression system, LMF, Neuman \& Esser. All compressors are of horizontal type, equipped with double acting cylinders.

Figure 1 illustrates the cross section of a typical hydrogen reciprocating compressor equipped with double acting cylinders.

The overall assessment of maintenance management relating to various types of hydrogen compressors requires one structural model of these compressors. The structural analysis of compressors was performed using the hierarchy proposed in [3]: 


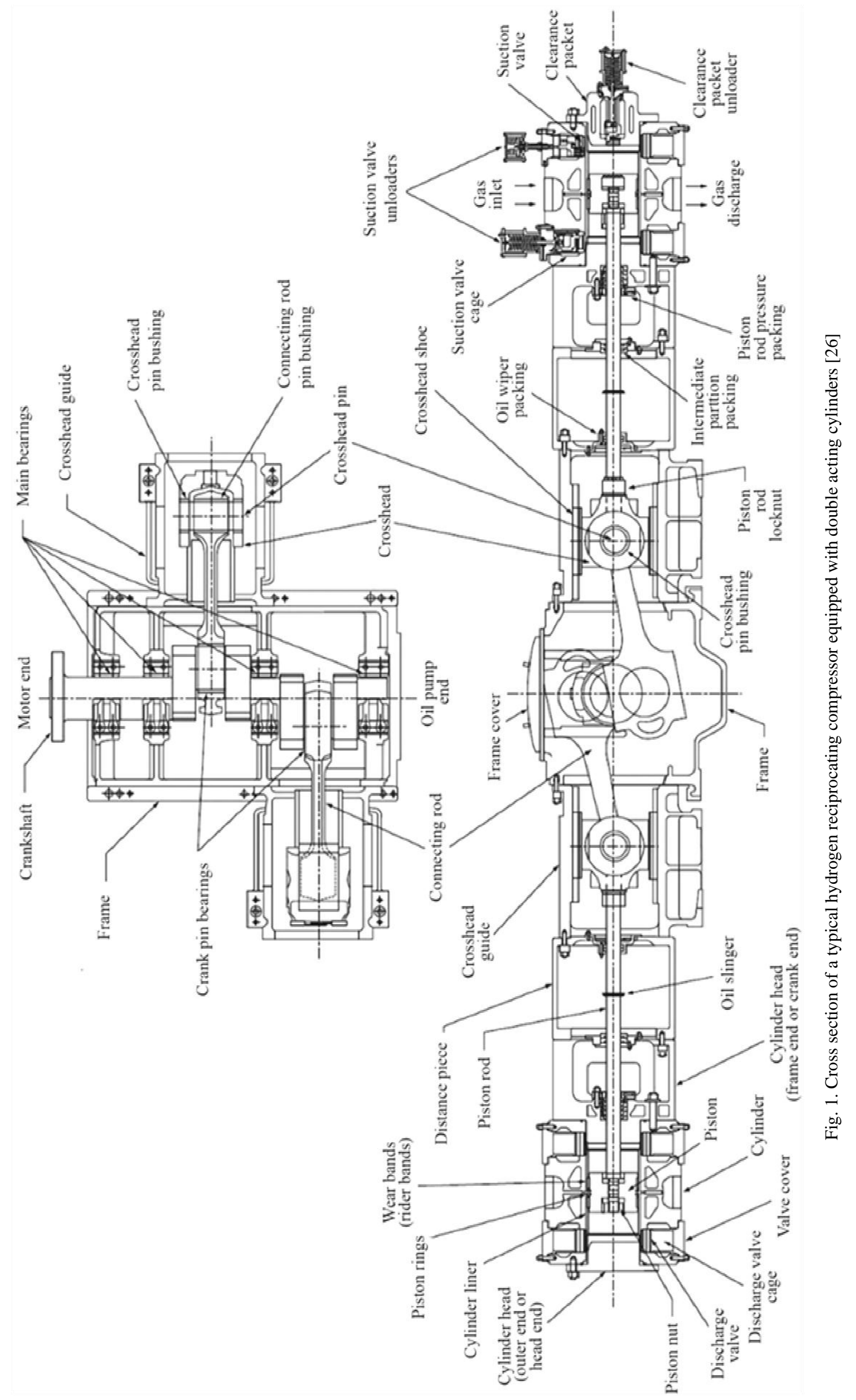


Table 1. Hydrogen piston compressors at Grupa LOTOS SA refinery

\begin{tabular}{|l|c|c|c|c|c|c|}
\hline Producer & $\begin{array}{c}\text { No. } \\
\text { of cylinder }\end{array}$ & $\begin{array}{c}\text { No. } \\
\text { of stage }\end{array}$ & $\begin{array}{c}\text { Power } \\
{[\mathrm{kW}]}\end{array}$ & $\begin{array}{c}\text { Suction } \\
\text { pressure }[\mathrm{kPa}]\end{array}$ & $\begin{array}{c}\text { Discharge } \\
\text { pressure }[\mathrm{kPa}]\end{array}$ & $\begin{array}{c}\text { Capacity } \\
{\left[\mathrm{Nm}^{3} / \mathrm{h}\right]}\end{array}$ \\
\hline Nuovo Pignone & 2 & 1 & 600 & 1370 & 2870 & 18324 \\
\hline Nuovo Pignone & 2 & 1 & 600 & 1370 & 2870 & 18324 \\
\hline Thermodyn & 2 & 2 & 1562 & 610 & 3880 & 18441 \\
\hline Thermodyn & 2 & 2 & 1562 & 610 & 3880 & 18441 \\
\hline Thermodyn & 2 & 2 & 1562 & 610 & 3880 & 18441 \\
\hline Nuovo Pignone & 2 & 1 & 280 & 2000 & 2800 & 11250 \\
\hline Nuovo Pignone & 2 & 1 & 280 & 2000 & 620 & 11250 \\
\hline Nuovo Pignone & 1 & 1 & 56 & 150 & 620 & 895 \\
\hline Nuovo Pignone & 1 & 1 & 56 & 150 & 9830 & 37968 \\
\hline LMF & 4 & 2 & 1570 & 3900 & 9830 & 37968 \\
\hline LMF & 4 & 2 & 1570 & 3900 & 18960 & 28165 \\
\hline Nuovo Pignone & 3 & 3 & 2850 & 2340 & 18960 & 28165 \\
\hline Nuovo Pignone & 3 & 3 & 2850 & 2340 & 18960 & 28165 \\
\hline Nuovo Pignone & 3 & 3 & 2850 & 2340 & 18211 & 51829 \\
\hline Nuovo Pignone & 2 & 2 & 3310 & 4227 & 18211 & 51829 \\
\hline Nuovo Pignone & 2 & 2 & 3310 & 4227 & 3590 & 51829 \\
\hline Nuovo Pignone & 2 & 2 & 3310 & 4227 & 4719 & 5640 \\
\hline Thomassen & 2 & 2 & 421 & 585 & 4719 & 42008 \\
\hline Neuman \& Esser & 2 & 1 & 1650 & 2494 & 4719 & 42008 \\
\hline Neuman \& Esser & 2 & 1 & 1650 & 2494 & & 42008 \\
\hline Neuman \& Esser & 2 & 1 & 1650 & 2494 & & \\
\hline
\end{tabular}

- compressors systems,

- functional units,

- elements of functional units.

Two systems, cylinder and crank, are separately considered. Although in many cases elements of functional units are not parts of machines from designer's viewpoint, the following decomposition is introduced for the purpose of this work.

The cylinder system we distinguish the following functional units:

- timing, functional unit elements: suction valve, discharge valve;

- unloading of suction valve, functional unit elements: unloader, actuator;

- piston guide in cylinder liner, functional unit elements: rider band, piston, cylinder liner, oil;

- compression chamber, functional unit elements: piston ring, cylinder liner, piston, cylinder head, pressure packing, intermediate packing, piston rod;

- crosshead bearing, functional unit elements: crosshead, crosshead shoe, crosshead guide, bolted joint, oil;

- cylinder lubrication, functional unit elements: multistage oil pump.

In the crank system the following functional units are set apart:

- crankcase sealing, functional unit elements: oil wiper packing, piston rod;

- connecting rod small end bearing, functional unit elements: crosshead pin, crosshead, crosshead pin bushing, connecting rod, oil;

- crankpin bearing, functional unit elements: crankshaft (crankpin), crankpin bearing shells, connecting rod, bolted joint, oil;
- journal bearing, functional unit elements: crankshaft (journal), main bearing shells, main bearing support, bolted joint, oil;

- thrust bearing, functional unit elements: thrust shoe, thrust collar, crankshaft (web), main bearing support, bolted joint, oil;

- bearings lubrication, functional unit elements: main oil pump, auxiliary oil pump.

\section{FAULT STATISTICS}

Based on post-repair documentation [Post-repair documentation in possession of Grupa LOTOS S.A.] of 21 machines (Table 1) maintained according to their service life, and making use of technical diagnostics, we calculated the percentage share of failures of compressor systems, functional units and selected elements of functional units. The analysis covered faults recorded over the last 20 years. For the statistical purposes, we also considered as damaged elements those that, retaining their wear margin, reached the end of their expected service life.

The results of the conducted studies show that the percentage share of failures that occurred to hydrogen piston compressor systems at the installations of Grupa LOTOS S.A. refinery it remains as follows:

- cylinder $-87.7 \%$,

- crank-10.9\%,

- others $-1.4 \%$.

The bar graphs shown in Fig. 2-5 illustrate the percentage shares of functional unit failures of those systems and their elements in reference to the total number of failures. 


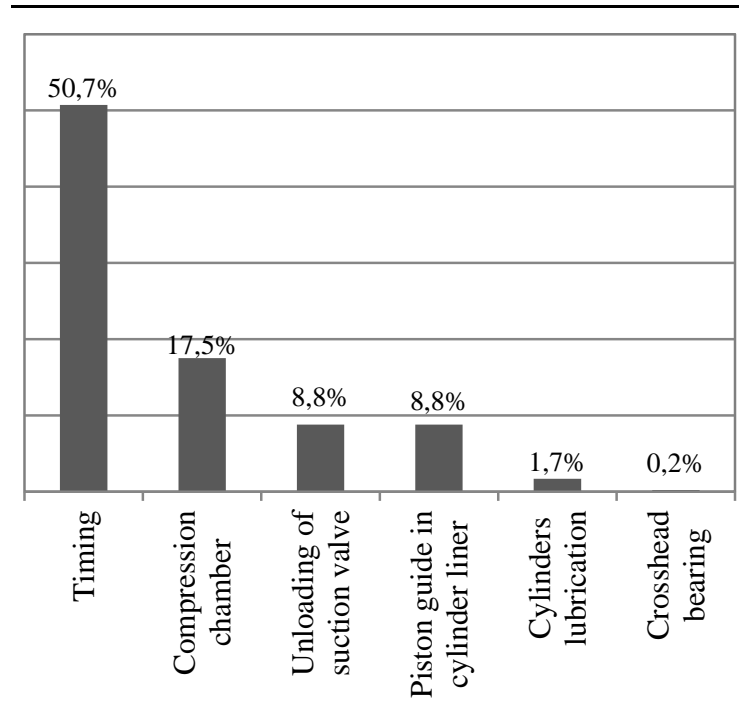

Fig. 2. Percentage share of functional unit failures in hydrogen piston compressor cylinder systems, Grupa LOTOS S.A. refinery

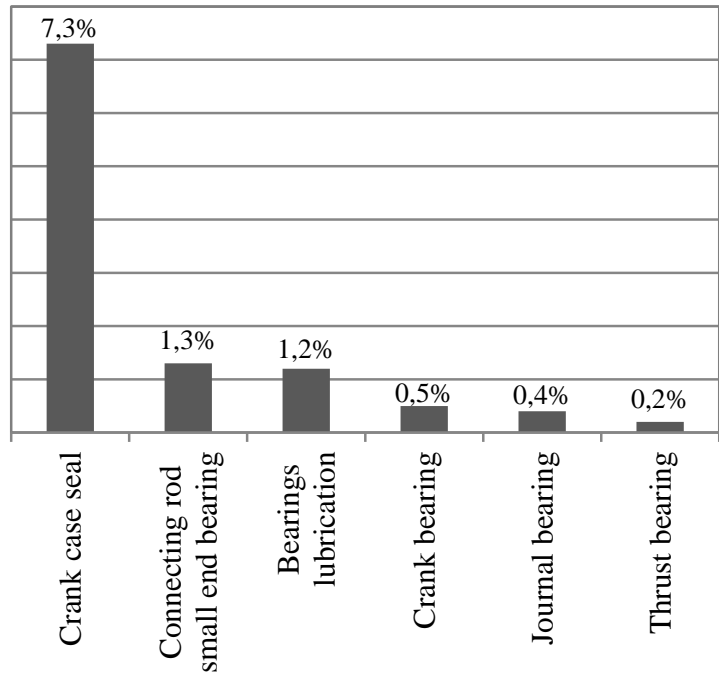

Fig. 3. Percentage share of functional unit failures in hydrogen piston compressor crank systems, Grupa LOTOS S.A. refinery

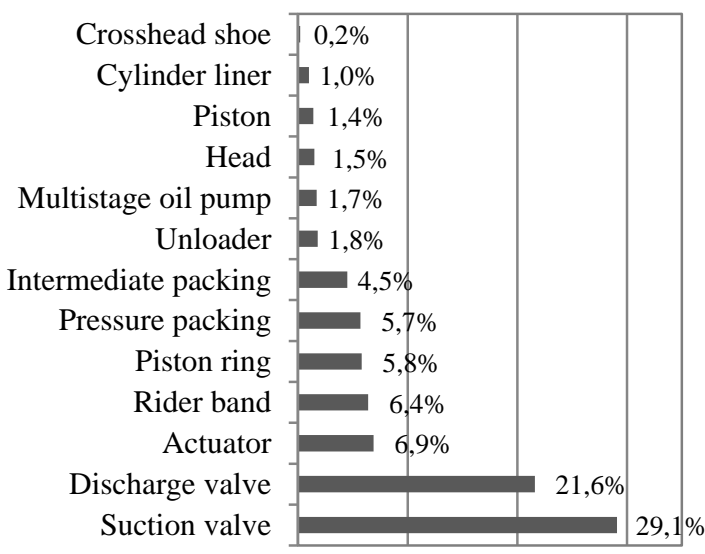

Fig. 4. Percentage share of element failures in hydrogen piston compressor cylinder systems, Grupa LOTOS S.A. refinery

The highest percentage share of functional unit failures in cylinder systems falls on timing (50.7\%),

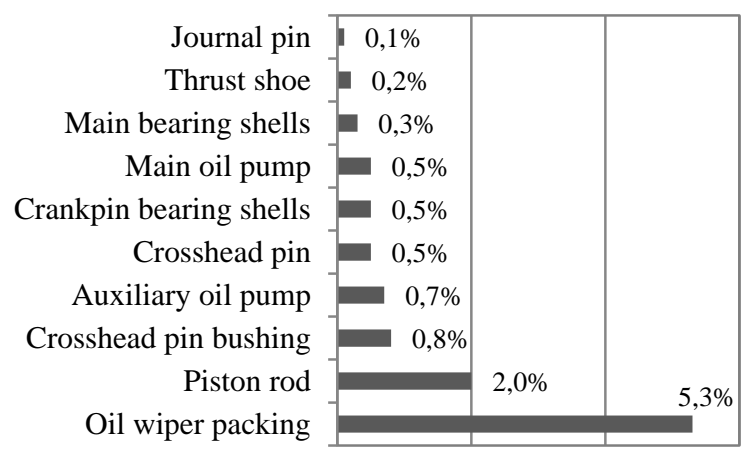

Fig. 5. Percentage share of element failures in hydrogen piston compressor crank systems, Grupa LOTOS S.A. refinery

followed by compression chamber $(17.5 \%)$. Crankcase seal $(7.3 \%)$ and connecting rod small end bearing $(1.3 \%)$ functional units have the two highest percentage shares of failures in the crank systems. Among failures of single elements of cylinder systems, the most common failures are those of valves: suction $(29.1 \%)$ and discharge $(21.6 \%)$. Oil wiper packing $(5.3 \%)$ and piston rod $(2.0 \%)$ considered as elements have the highest failure percentage share in the crank system.

\section{FAILURE RISK}

The risk of failure occurrence is defined as the product of the failure frequency (probability of failure) and the cost of eliminating the effects of the failure. The costs of removing the failure effects include, among others, downtime. In production systems with redundant compressors and variable demand for hydrogen, the probability of suspending production also varies and depends on that demand. It is advisable to create an appropriate algorithm for calculating the failure risk in systems with redundancy. This calls for the creation and use of an appropriate algorithm for calculating actual costs of maintenance and losses due to downtime caused by failures. This will allow, once a maintenance innovation is implemented (e.g. diagnostic tool or method) to assess the effectiveness and efficiency such innovation. Due to difficulties in comparing costs incurred within 20 years, for the purposes of this paper instead of determining the risk we estimated risk indicators.

Estimation of failure risk indicators $R$ for systems, functional units and elements of hydrogen piston compressors was based on the following equation:

$$
x(m+p+e+i)=R
$$

where:

$x$ - number of failures,

$m$ - material cost factor,

$p$ - repair work cost factor,

$e-$ cost factor arising from wear margin loss,

$i$ - cost factor arising from difficulties in identifying a failure. 
Material and work cost factors were estimated from average real costs, taking into account possible reconditioning. At this stage of the analysis, costs of repair work and those arising from system's wear margin loss come down only to the duration of repair activity including preparatory work. The cost factor resulting from identifying a failure was estimated using an expert method, comprising both element quality assessment as well as diagnostic methods. Considering the above it can be stated that the risk indicators $R$ for the hydrogen compressor systems at the Grupa LOTOS S.A. refinery it remain at these levels:

- cylinder -8138 ,

- crank - 1307.

The bar graphs in Fig. 6-9 show the risk indicator $R$ for functional units of those systems and their elements.

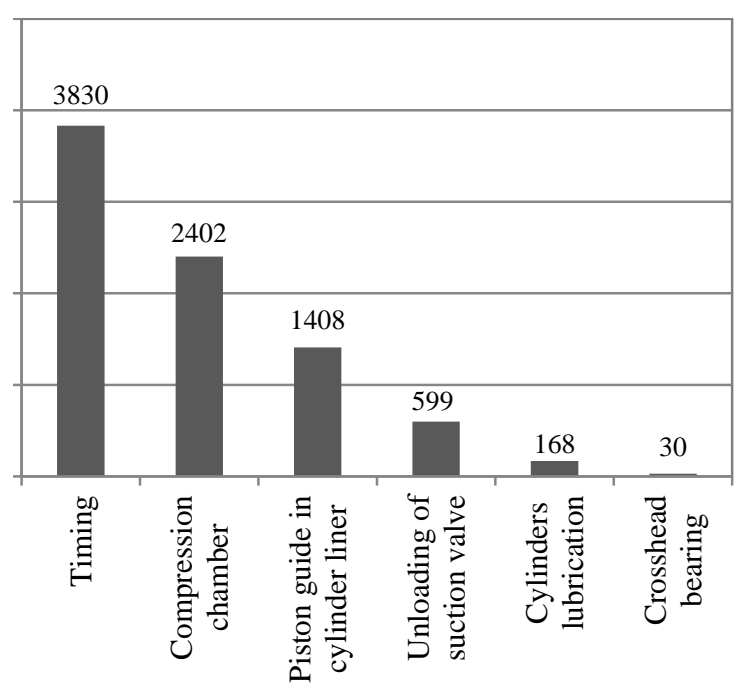

Fig. 6. Values of failure risk indicator $R$ for hydrogen piston compressors, cylinder system functional units at the Grupa LOTOS S.A. refinery

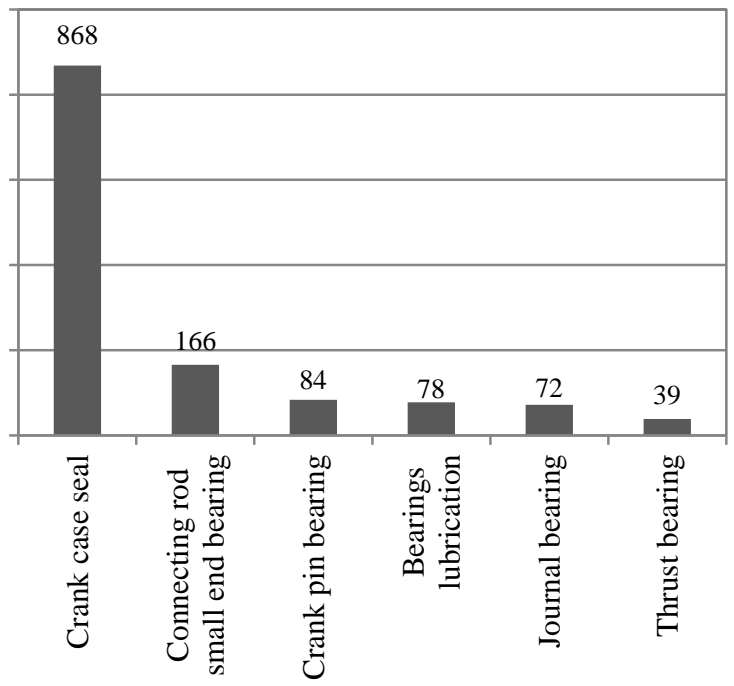

Fig. 7. Values of failure risk indicator $R$ for hydrogen piston compressors, crank system functional units at the Grupa LOTOS S.A. refinery
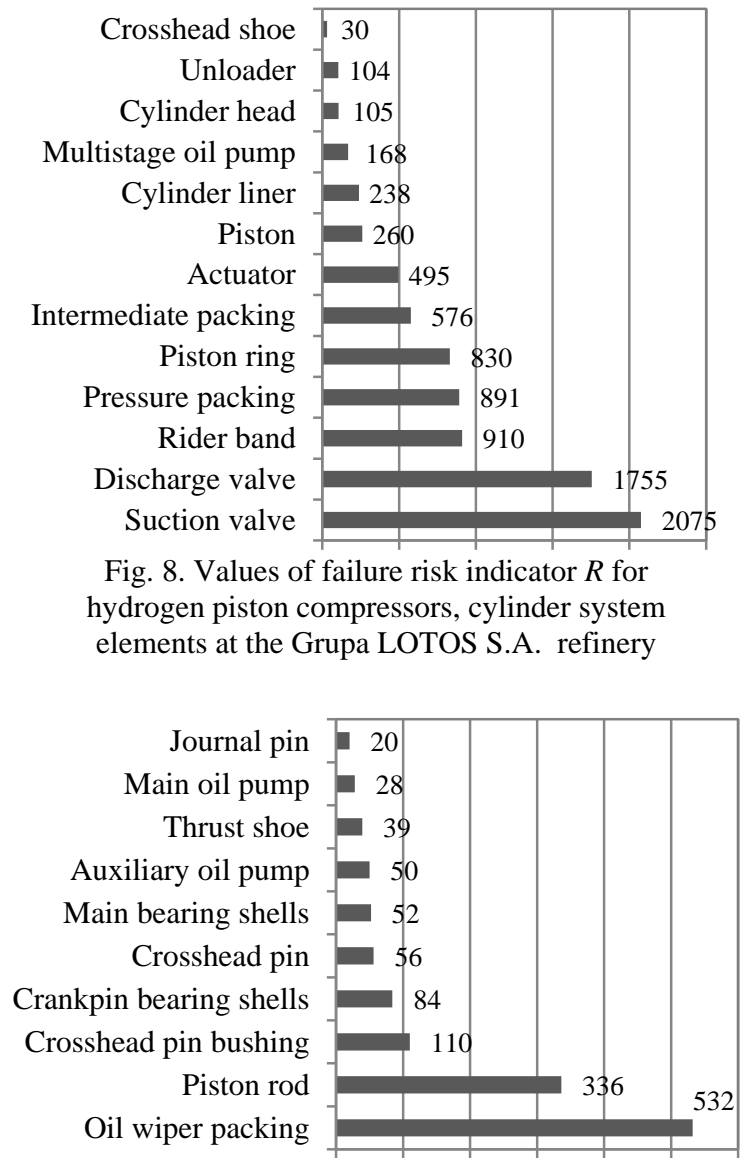

Fig. 9. Values of failure risk indicator $R$ for hydrogen piston compressors, crank system elements at the Grupa LOTOS S.A. refinery

The highest values of failure risk indicator $R$ in the cylinder system fall on timing $(R=3830)$ and compression chamber $(R=2402)$ functional units. The crankcase seal $(R=868)$ and connecting rod small end bearing $(R=166)$ functional units have the highest value of failure risk indicator $R$ in the crank system. In case of single elements in the cylinder system, suction $(R=2075)$ and discharge $(R=1755)$ valves are burdened with the highest value of failure risk indicator $R$, while in the crank system, oil wiper packing $(R=532)$ and piston rod $(R=336)$ take the lead.

\section{WEAR TYPES OF COMPRESSOR COMPONENTS WITH THE HIGHEST FREQUENCY OF FAILURE}

Elements of functional units are subject to characteristic damage. Failures of main compressor functional unit elements with the highest frequency and failure risk indicator are discussed below, along with typical failures, mechanisms and causes.

\subsection{Valves}

- Damage caused by heavy contamination; due to technological process disturbances, compressors may work with highly contaminated gas, which may cause erosive wear of valve elements and lead to their complete bonding. 


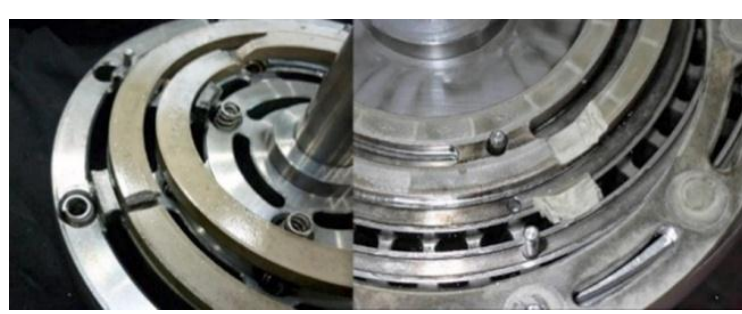

Fig. 10. Broken valve seal rings

- Fatigue wear (cracks) of valve sealing rings (Fig. 10), and valve springs as a result of cyclic mechanical and thermal loads; in this case secondary damage often occurs.

- Wear of valve components caused by excessive amount of cylinder lubricating oil - sticky rings effect; as a result of adhesive forces acting between the lube oil film and the ring, seat and stopper there will be valve ring sticking effect. The value of the force resulting from pressure difference needed to open and close the valve will be increasing, resulting in larger impact energy of the rings on the valve seat and the stopper. Valve rings will be subjected in such conditions to higher mechanical loads.

- Damage to valve seats.

\subsection{Piston rings and rider bands}

- Heavily contaminated gas medium may result in rings blocking in grooves, which reduces their sealing ability. Contaminants may also substantially increase the friction between the active surface of piston rings and the cylinder liner surface - resulting in increased tribological wear of those elements.

- Fatigue wear, i.e. cracks, accompanied by serious secondary damage in case of a fracture.

- Normal tribological wear.

- Rider bands adhesive wear (Fig. 11).

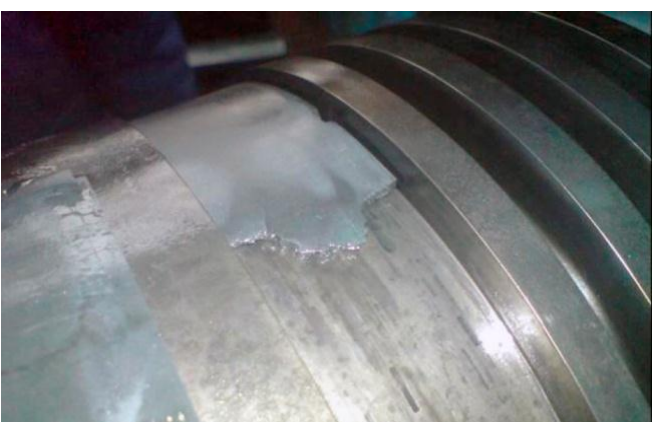

Fig. 11. Rider bands damage

\subsection{Piston rod packings}

- Tribological wear of pressure and intermediate packing carbon rings and oil wipers. The accelerating effect here is due to contamination (Fig. 12), inadequate lubrication (pressure packing) and insufficient heat removal as a result of cooling systems failure. Contaminations should be understood as insufficiently pure process gas, as well as wear products of the sealings themselves.

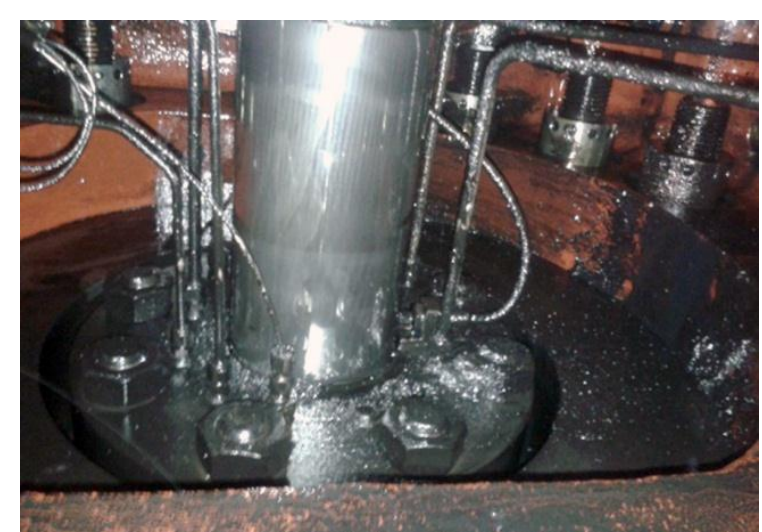

Fig. 12. Contamination of pressure packing

\subsection{Piston rods}

- Tribological wear of piston rods in packings working area - polishing. 'Mirror' surfaces with too low roughness contribute to larger leaks.

- Ruining the piston rods surfaces due to their cutting by hard particles from damaged packing - secondary damage.

\subsection{Pistons}

- Secondary tribological wear (Fig. 13), abrasion and adhesion caused by rider bands wear inappropriate guiding of the piston in the cylinder liner.

- Piston ring grooves get worn due to cyclic mechanical and tribological loads.

- Cracks formed by mechanical stress concentrations - the notch effect.

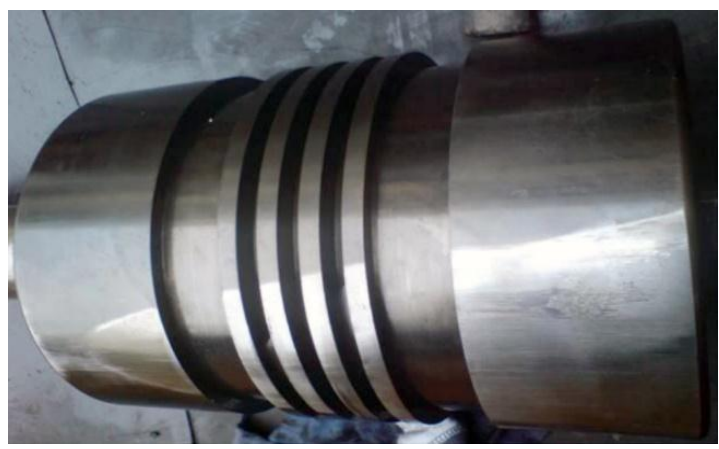

Fig. 13. Tribological wear of piston

\subsection{Cylinder liners}

- Tribological wear, abrasion and adhesion contaminants as an amplifying factor.

- Fatigue wear (pitting) of cylinder liner surface (Fig. 14).

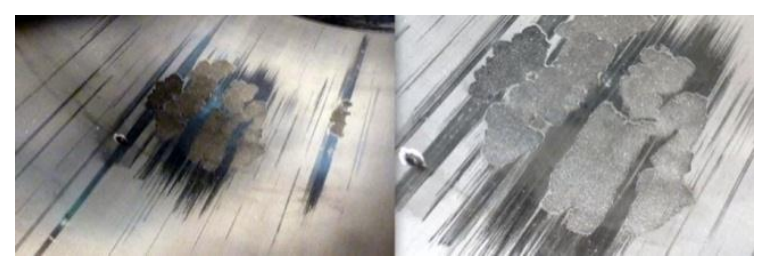

Fig. 14. Pitting of cylinder liner surfaces 
This characteristic effect of this wear is decreased tightness of the pressure chamber caused by contamination and/or increased clearances. The purity of compressed hydrogen has high impact on wear intensity. Moreover, in specific pressure and temperature conditions water contained in hydrogen may condense, causing damage to working valves. Taking into account the flow capacity of valves, a certain volume compressible liquid in the cylinder can lead to the surge phenomenon, which can cause serious cylinder and crank systems failures.

\section{DIAGNOSTICS OF HYDROGEN RECIPROCATING COMPRESSORS.}

A failure is an undesired, often unpredictable event. This event is of destructive character and, depending on the characteristics and functions of a defective component, carries a large risk. In order to avoid further identical failures, their causes should be identified through a failure analysis, then, if possible, the causes should be eliminated. Eliminating the cause of damage is done through changes in operation, repair technology or machine design. However, it is not always possible or cost-effective. In such a case, preventive actions should be implemented in the form of diagnostics. The early disclosure of wear symptoms will significantly reduce the costs of repair and will allow for repair planning. According to studies [1, 2 , $6,8,9,10,12,14,15,22,25,29,30,31,32,33,34]$ conclusions can be drawn on damage or wear of components and functional units of reciprocating compressors on the basis of:

1. absolute vibration values;

2. noise measurement;

3. piston drop values/piston rod position;

4. $\mathrm{p} / \mathrm{v}$ diagrams;

5. rod load diagrams;

6. values of leakage at piston rod seals.

7. suction and discharge pressure values;

8. suction and discharge differential pressure values;

9. content of wear products in lubrication oil;

10. power consumption;

11. compressor capacity value;

12. temperature values of:
a. main bearings;
b. valve seats;
c. pressure packing;
d. process gas;
e. lubrication oil;
f. cooling fluid;

However, it should be noted that the diagnostics of piston compressors is difficult in terms of interpreting the results. Single, independently recorded diagnostic symptoms can lead to false and often contradictory conclusions. The aim should be to create integrated diagnostic systems, enabling diagnostic tests based on an analysis of many values recorded and analyzed as a function of machine operating parameters.

\section{CONCLUSIONS}

The authors have found that the highest percentage share of failures and the highest risk of wear margin loss characterize the timing functional unit (with suction and discharge valves). Other functional units subject to failure include compression chamber, piston guide in the cylinder liner and crankcase seals. In view of the findings, it seems advisable to create a super cylinder system, including valves and oil wiper packing, and to search for methods and tools of failure risk reduction for such system. It is essential to create an algorithm for risk estimation and calculation of real costs and losses that would also allow assessing the efficiency and effectiveness of implemented diagnostic methods and tools. Characteristic features of that super system are as follows:

- the moving elements of the functional units perform reciprocating motion, synchronous with the rotation angle of the crankshaft. Reciprocation is accompanied by transverse motion whose characteristics have values dependent on load and wear margin of the running functional units;

- damage to each functional unit leads to decreasing tightness;

- secondary damage makes up a substantial portion of failures.

\section{REFERENCES}

1. Ahmed M, Gu F, Ball AD. Fault detection of reciprocating compressors using a model from principles component analysis of vibrations. Journal of Physics: Conference series 364, IOP Publishing, 2012. http://dx.doi.org/10.1088/1742-6596/364/1/012133.

2. Bielawski P. Elements of vibration diagnostics of ship engines piston-crank mechanisms. Maritime University of Szczecin, 2002. Szczecin, Poland.

3. Bielawski P. Identification of technical objects of production systems. Maritime University of Szczecin, 2014. Szczecin, Poland.

4. Bielawski P. Measurements and limits of the machine wear margin of production systems. Journal of Machine Construction and Maintenance. Maintenance Problems, 2016;1: 129-139.

5. Bloch H, Hoefner J.: Reciprocating compressors: operation and maintenance. Gulf Publishing Company, 1996. Houston, TX.

6. Cui H, Zhang L, Kang R, Lan X. Research on fault diagnosis for reciprocating compressor valve using information entropy and SVM method. Journal of Loss Prevention in the Process Industries, 2009; 22(6): 864-867. http://dx.doi.org/10.1016/j.jlp.2009.08.012

7. Downarowicz O. Genesis and Present State of Technological Resources Management. Inżynieria Morska i Geotechnika, 1999/6, pages: 319-325.

8. Farzaneh-Gord M, Khoshnazar H. Valve fault detection for single-stage reciprocating compressors. 
Journal of Natural Gas Science and Engineering, 2016; 35: $1239-1248$

http://dx.doi.org/10.1016/j.jngse.2016.09.062

9. Füner V. Indiziren kleinster motorverdichter. Kältetechnik, 1960/3, pages: 66-70, 1960/10, pages: 298-302.

10. Lankenau H. Fluch und Segen des Condicion Monitoring bei Kolbenkompressoren. Industriepumpen + Kompressoren, 1/2007: 22-28.

11. LMF reciprocating compressor type 13244-228 S 9.8. Technical documentation.

12. Loukopoulos P., Zolkiewski G., Benett I., Sampath S., Pilidis P., Duan F., Sattar T., Mba D.: Reciprocating compressor prognostics of an instantaneous failure mode utilizing temperature only measurements. Applied Acoustics, 2017; 12. http://dx.doi.org/10.1016/j.apacoust.2017.12.003

13. Machinery Protection Systems. API Standard 670 fourth edition, December 2000.

14. Manepatil SS, Tiwari A. Fault diagnosis of reciprocating compressor using pressure pulsations. International Compressor Engineering Conference, paper 1819. 2006.

15. Nickol J. Kompressorendiagnose in der praxis. Industriepumpen + Kompressoren, 4/2000 pages: 282285.

16. Neuman \& Esser reciprocating compressor type 1TZL300. Technical documentation.

17. Nuovo Pignone (now GE Oil \& Gas) reciprocating compressor type $2 \mathrm{HC} / 1$. Technical documentation.

18. Nuovo Pignone (now GE Oil \& Gas) reciprocating compressor type $2 \mathrm{HB} / 1$. Technical documentation.

19. Nuovo Pignone (now GE Oil \& Gas) reciprocating compressor type 2HG/2. Technical documentation.

20. Nuovo Pignone (now GE Oil \& Gas) reciprocating compressor type $4 \mathrm{HF} / 3$. Technical documentation.

21. Nuovo Pignone (now GE Oil \& Gas) reciprocating compressor type OA/1. Technical documentation.

22. Pichler K, Lughofer E, Pichler M, Buchegger T, Klement EP, Huschenbett M. Fault detection in reciprocating compressor valves under varying load conditions. Mechanical Systems and Signal Processing, volumes 70-71, 3/2016, pages: 104-119. http://dx.doi.org/10.1016/j.ymssp.2015.09.005

23. PN-EN 13306: 2006. Terminologia dotycząca obsługiwania.

24. Post-repair documentation in possession of Grupa LOTOS S.A.

25. Rosenberg T, Schuhmann R. Überwachung von Kolbenverdichtern aus Sicht eines Betreibers. Industriepumpen + Kompressoren, 2/2010: 70-74.

26. Reciprocating Compressors for Petroleum, Chemical, and Gas Industry Services. API Standard 618 sixth edition, December 2013.

27. Thermodyn (now GE Oil \& Gas) reciprocating compressor type KM2. Technical documentation.

28. Thomassen Compression system reciprocating compressor type C7-2. Technical documentation.

29. Townsend J, Affan Badar M, Szekerces J. Updating temperature monitoring on reciprocating compressor connecting rods to improve reliability. Engineering
Science and Technology an International Journal, 2016; 19: 566-573.

30. Tung Tran V., AlThobiani F., Ball A.: An approach to fault diagnosis of reciprocating compressor valves using Teager-Kaiser energy operator and deep belief networks. Expert Systems with Applications, 2014; 41(9): 4113-4122.

http://dx.doi.org/10.1016/j.eswa.2013.12.026

31. Urbansky M.: Influence of piston compressor inner failure on mechanical system objective function. Diagnostyka, 2016, 17(3): 47-52.

32. Wang F., Zhang Y., Xu Y., Wang J., Fu X.: Design on intelligent diagnosis system of reciprocating compressor based on multi-agent technique. Procedia Engineering, 2012, 29: 3256-3261.

33. Wang Y., Xue C., Jia X., Peng X.: Fault diagnosis of reciprocating compressor valve with the method integrating acoustic emission signal simulated valve motion. Mechanical Systems and Signal Processing, 2015; 56-57: 197-212. http://dx.doi.org/10.1016/j.ymssp.2014.11.002

34. Zhao J, Wang S. Analysis for fatigue failure causes on a large-scale reciprocating compressor vibration by torsional vibration. Procedia Engineering, 2014; 74: 170-174.

Received 2017-07-24

Accepted 2018-01-15

Available online 2018-01-22

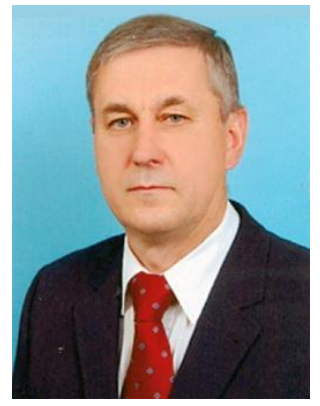

Piotr Jan BIELAWSKI, a professor at the Condition Monitoring and Maintenance of Machinery Department, Maritime University of Szczecin. His research is focused on the maintenance of ship machines: identification of elements, machine assembly, repairs of machines and machine elements, diagnostics of machines, with a focus on diagnostics of reciprocating machines.

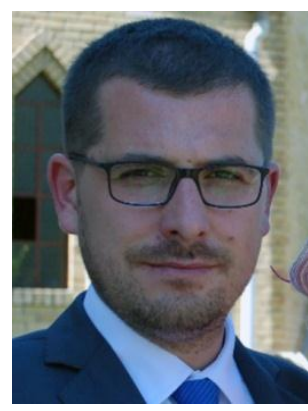

Pawel BIALEK, M.Sc. Eng. Maintenance Department Engineer at Grupa LOTOS S.A. refinery in Gdańsk. His scientific interests are focused on Maintenance of Refinery Machines: Identification of Elements, Assembly of Machines, Repairs of Machines and Machine Elements, Wear Analysis of Machine Elements, Diagnostic of Machines particularly Diagnostic of Reciprocating Compressors. 